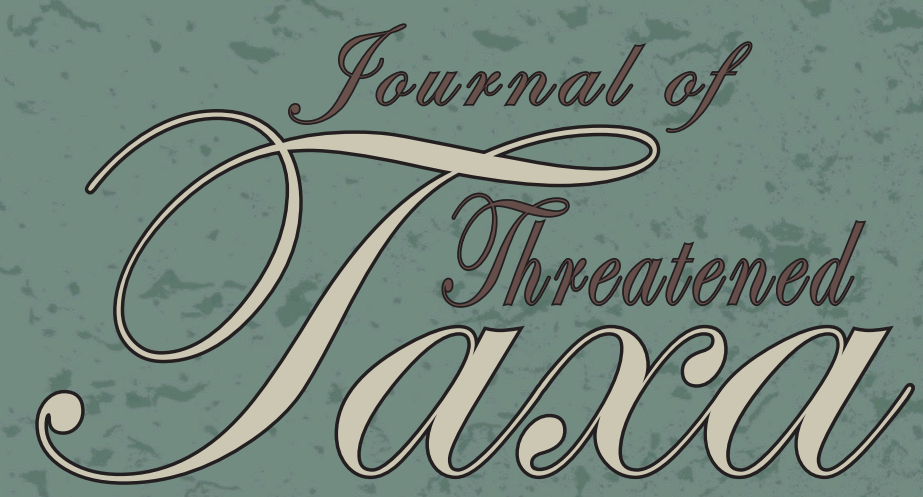

Building evidence for conservation globally
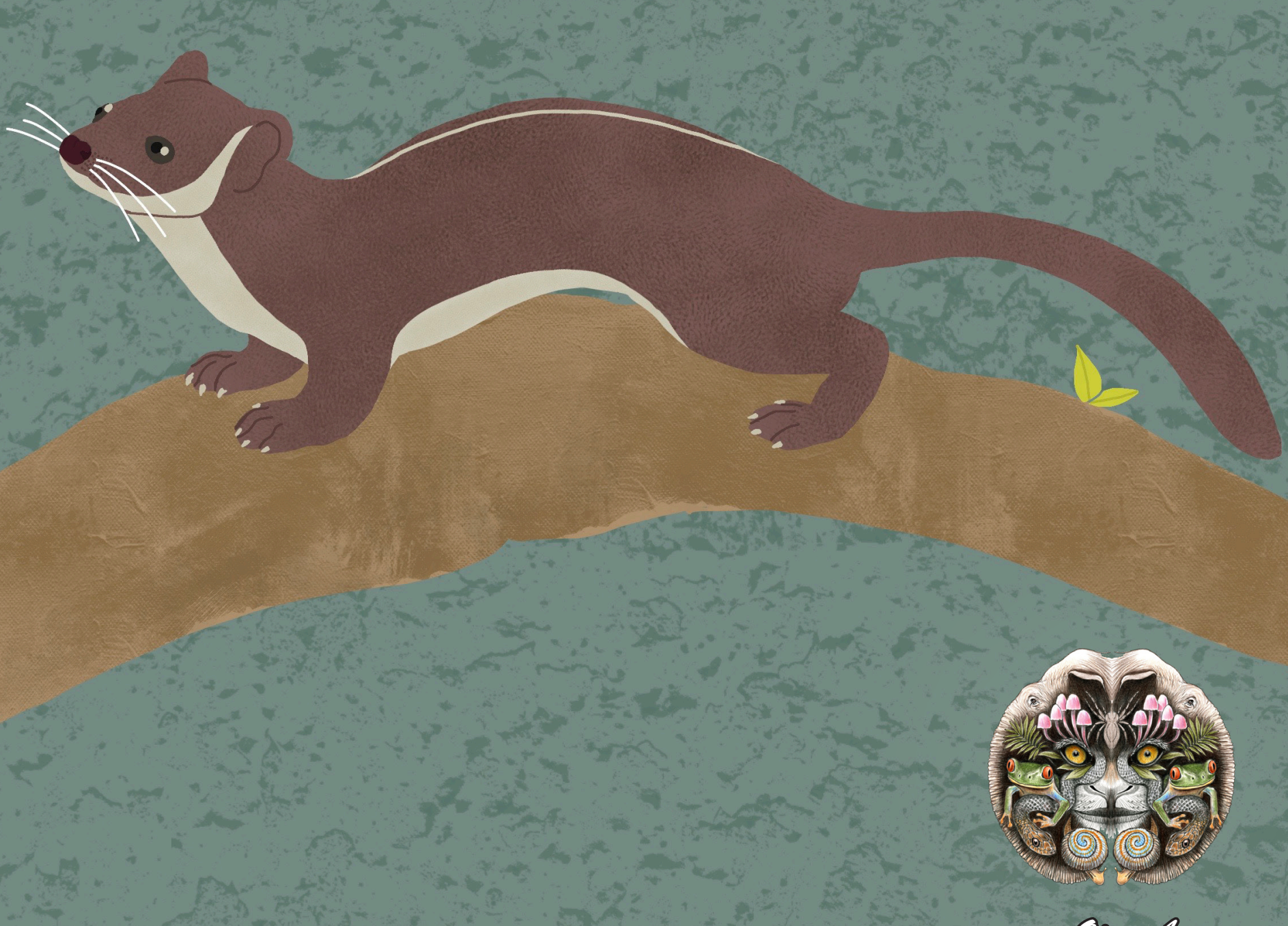

Qpecosecess

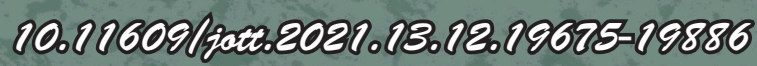
cocosurthreatecredtassararg

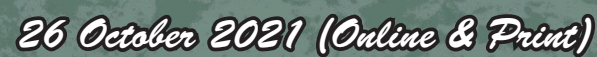

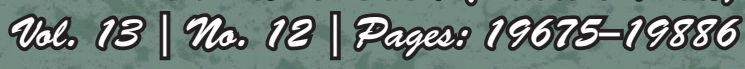




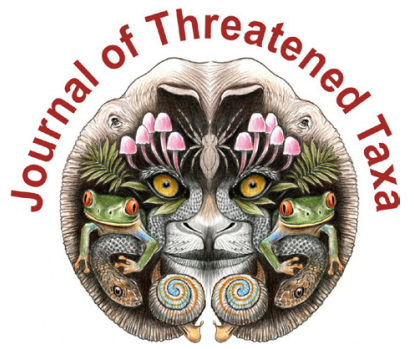

ISSN 0974-7907 (Online); ISSN $0974-7893$ (Print)

Publisher

Host

Wildlife Information Liaison Development Society

www.wild.zooreach.org

Zoo Outreach Organization www.zooreach.org

No. 12, Thiruvannamalai Nagar, Saravanampatti - Kalapatti Road, Saravanampatti, Coimbatore, Tamil Nadu 641035, India

Ph: +91 9385339863 | www.threatenedtaxa.org

Email: sanjay@threatenedtaxa.org

EDITORS

\section{Founder \& Chief Editor}

Dr. Sanjay Molur

Wildlife Information Liaison Development (WILD) Society \& Zoo Outreach Organization (ZOO)

12 Thiruvannamalai Nagar, Saravanampatti, Coimbatore, Tamil Nadu 641035, India

\section{Deputy Chief Edito}

Dr. Neelesh Dahanukar

Noida, Uttar Pradesh, India

\section{Managing Editor}

Mr. B. Ravichandran, WILD/ZOO, Coimbatore, India

\section{Associate Editors}

Dr. Mandar Paingankar, Government Science College Gadchiroli, Maharashtra 442605, India Dr. Ulrike Streicher, Wildlife Veterinarian, Eugene, Oregon, USA

Ms. Priyanka Iyer, ZOO/WILD, Coimbatore, Tamil Nadu 641035, India

Dr. B. A. Daniel, $200 /$ WIID, Coimbatore, Tamil Nadu 641035, India

\section{Editorial Board}

Dr. Russel Mittermeie

Executive Vice Chair, Conservation International, Arlington, Virginia 22202, USA

\section{Prof. Mewa Singh Ph.D., FASc, FNA, FNASc, FNAPsy}

Ramanna Fellow and Life-Long Distinguished Professor, Biopsychology Laboratory, and Institute of Excellence, University of Mysore, Mysuru, Karnataka 570006, India; Honorary Professor, Jawaharlal Nehru Centre for Advanced Scientific Research, Bangalore; and Adjunct Professor, National Institute of Advanced Studies, Bangalore

\section{Stephen D. Nash}

Scientific Illustrator, Conservation International, Dept. of Anatomical Sciences, Health Sciences Center, T-8, Room 045, Stony Brook University, Stony Brook, NY 11794-8081, USA

\section{Dr. Fred Pluthero}

Toronto, Canada

\section{Dr. Priya Davidar}

Sigur Nature Trust, Chadapatti, Mavinhalla PO, Nilgiris, Tamil Nadu 643223, India

\section{Dr. Martin Fisher}

Senior Associate Professor, Battcock Centre for Experimental Astrophysics, Cavendish

Laboratory, JJ Thomson Avenue, Cambridge CB3 OHE, UK

\section{Dr. John Fellowes}

Honorary Assistant Professor, The Kadoorie Institute, 8/F, T.T. Tsui Building, The University of Hong Kong, Pokfulam Road, Hong Kong

\section{Prof. Dr. Mirco Solé}

Universidade Estadual de Santa Cruz, Departamento de Ciências Biológicas, Vice-coordenado do Programa de Pós-Graduação em Zoologia, Rodovia Ilhéus/Itabuna, Km 16 (45662-000)

Salobrinho, Ilhéus - Bahia - Brasil

\section{Dr. Rajeev Raghavan}

Professor of Taxonomy, Kerala University of Fisheries \& Ocean Studies, Kochi, Kerala, India

\section{English Editors}

Mrs. Mira Bhojwani, Pune, India

Dr. Fred Pluthero, Toronto, Canad

Mr. P. Ilangovan, Chennai, India

Web Maintenance

Mrs. Latha G. Ravikumar, ZOO/WILD, Coimbatore, India

\section{Typesetting}

Mr. Arul Jagadish, ZOO, Coimbatore, India

Mrs. Radhika, ZOO, Coimbatore, India

Mrs. Geetha, ZOO, Coimbatore India

\section{Fundraising/Communications}

Mrs. Payal B. Molur, Coimbatore, India

Subject Editors 2018-2020

Fungi

Dr. B. Shivaraju, Bengaluru, Karnataka, India

Dr. R.K. Verma, Tropical Forest Research Institute, Jabalpur, India

Dr. Vatsavaya S. Raju, Kakatiay University, Warangal, Andhra Pradesh, India

Dr. M. Krishnappa, Jnana Sahyadri, Kuvempu University, Shimoga, Karnataka, India

Dr. K.R. Sridhar, Mangalore University, Mangalagangotri, Mangalore, Karnataka, India

Dr. Gunjan Biswas, Vidyasagar University, Midnapore, West Bengal, India

Plants

Dr. G.P. Sinha, Botanical Survey of India, Allahabad, India

Dr. N.P. Balakrishnan, Ret. Joint Director, BSI, Coimbatore, India

Dr. Shonil Bhagwat, Open University and University of Oxford, UK

Prof. D.J. Bhat, Retd. Professor, Goa University, Goa, India

Dr. Ferdinando Boero, Università del Salento, Lecce, Italy

Dr. Dale R. Calder, Royal Ontaro Museum, Toronto, Ontario, Canada

Dr. Cleofas Cervancia, Univ. of Philippines Los Baños College Laguna, Philippines

Dr. F.B. Vincent Florens, University of Mauritius, Mauritius

Dr. Merlin Franco, Curtin University, Malaysia

Dr. V. Irudayaraj, St. Xavier's College, Palayamkottai, Tamil Nadu, India

Dr. B.S. Kholia, Botanical Survey of India, Gangtok, Sikkim, India

Dr. Pankaj Kumar, Kadoorie Farm and Botanic Garden Corporation, Hong Kong S.A.R., China

Dr. V. Sampath Kumar, Botanical Survey of India, Howrah, West Bengal, India

Dr. A.J. Solomon Raju, Andhra University, Visakhapatnam, India

Dr. Vijayasankar Raman, University of Mississippi, USA

Dr. B. Ravi Prasad Rao, Sri Krishnadevaraya University, Anantpur, India

Dr. K. Ravikumar, FRLHT, Bengaluru, Karnataka, India

Dr. Aparna Watve, Pune, Maharashtra, India

Dr. Qiang Liu, Xishuangbanna Tropical Botanical Garden, Yunnan, China

Dr. Noor Azhar Mohamed Shazili, Universiti Malaysia Terengganu, Kuala Terengganu, Malaysia Dr. M.K. Vasudeva Rao, Shiv Ranjani Housing Society, Pune, Maharashtra, India

Prof. A.J. Solomon Raju, Andhra University, Visakhapatnam, India

Dr. Mandar Datar, Agharkar Research Institute, Pune, Maharashtra, India

Dr. M.K. Janarthanam, Goa University, Goa, India

Dr. K. Karthigeyan, Botanical Survey of India, India

Dr. Errol Vela, University of Montpellier, Montpellier, France

Dr. P. Lakshminarasimhan, Botanical Survey of India, Howrah, India

Dr. Larry R. Noblick, Montgomery Botanical Center, Miami, USA

Dr. K. Haridasan, Pallavur, Palakkad District, Kerala, India

Dr. Analinda Manila-Fajard, University of the Philippines Los Banos, Laguna, Philippines

Dr. P.A. Sinu, Central University of Kerala, Kasaragod, Kerala, India

Dr. Afroz Alam, Banasthali Vidyapith (accredited A grade by NAAC), Rajasthan, India

Dr. K.P. Rajesh, Zamorin's Guruvayurappan College, GA College PO, Kozhikode, Kerala, India

Dr. David E. Boufford, Harvard University Herbaria, Cambridge, MA 02138-2020, USA

Dr. Ritesh Kumar Choudhary, Agharkar Research Institute, Pune, Maharashtra, India

Dr. Navendu Page, Wildlife Institute of India, Chandrabani, Dehradun, Uttarakhand, India

Invertebrates

Dr. R.K. Avasthi, Rohtak University, Haryana, India

Dr. D.B. Bastawade, Maharashtra, India

Dr. Partha Pratim Bhattacharjee, Tripura University, Suryamaninagar, India

Dr. Kailash Chandra, Zoological Survey of India, Jabalpur, Madhya Pradesh, India

Dr. Ansie Dippenaar-Schoeman, University of Pretoria, Queenswood, South Africa

Dr. Rory Dow, National Museum of natural History Naturalis, The Netherlands

Dr. Brian Fisher, California Academy of Sciences, USA

Dr. Richard Gallon, llandudno, North Wales, LL30 1UP

Dr. Hemant V. Ghate, Modern College, Pune, India

Dr. M. Monwar Hossain, Jahangirnagar University, Dhaka, Bangladesh

Mr. Jatishwor Singh Irungbam, Biology Centre CAS, Branišovská, Czech Republic.

Dr. lan J. Kitching, Natural History Museum, Cromwell Road, UK

Dr. George Mathew, Kerala Forest Research Institute, Peechi, India

Dr. John Noyes, Natural History Museum, London, UK

For Focus, Scope, Aims, and Policies, visit https://threatenedtaxa.org/index.php/JoTT/aims_scope
For Article Submission Guidelines, visit https://threatenedtaxa.org/index.php/JoTT/about/submissions
For Policies against Scientific Misconduct, visit https://threatenedtaxa.org/index.php/JoTT/policies_various

continued on the back inside cover 


\title{
New distribution records of Begonia L., B. murina Craib and B. poilanei Kiew (Begoniaceae: Cucurbitales) for Laos
}

\author{
Phongphayboun Phonepaseuth ${ }^{1}$ (D), Phetlasy Souladeth ${ }^{2}$ (D), Soulivanh Lanorsavanh ${ }^{3}$ D, \\ Shuichiro Tagane ${ }^{4} \mathbb{D}$, Thyraphon Vongthavone ${ }^{5} \mathbb{D}$ \& Keooudone Souvannakhoummane ${ }^{6} \mathbb{C}$

\footnotetext{
${ }^{1}$ Faculty of Environmental Sciences, National University of Laos, Dongdok Campus, Xaythany District, Vientiane Capital, Laos.

${ }^{2}$ Faculty of Forestry Science, National University of Laos, Dongdok Campus, Xaythany District, Vientiane Capital, Laos.

${ }^{3,6}$ Faculty of Natural Science, National University of Laos, Dongdok Campus, Xaythany District, Vientiane Capital, Laos.

${ }^{4}$ The Kagoshima University Museum, Kagoshima University, 1-21-30 Korimoto, Kagoshima, 890-0065, Japan. ${ }^{5}$ Association for Community Development (ACD), Salavan Province, Laos.

${ }^{1}$ p.phonepaseuth@nuol.edu.la, ${ }^{2}$ p.souladeth@nuol.edu.la, ${ }^{3}$ biokklano@yahoo.com, ${ }^{4}$ stagane29@gmail.com, ${ }^{5}$ thyraphon@gmail.com, ${ }^{6}$ keooudone1988@gmail.com (corresponding author)
}

Abstract: Begonia murina Craib from central and B. poilanei Kiew from southern of Laos, are newly recorded in Laos. Based on Lao materials, detailed description, photographs, and notes on habitat, ecology, \& taxonomic discussion of these two species compared with the Chinese, Thai, \& Vietnamese types are provided.

Keyword: Bolaven plateau, description, flora of Laos, limestone karst, new record, taxonomic discussion.

Begonia L. (Begoniaceae) is one of the largest genera of angiosperms, comprising 1,989 accepted species (Hughes et al. 2015-). In Laos, 28 species have been recorded, nine of which are endemic (Ding et al. 2020; Lanorsavanh et al. 2020; Souvannakhoummane et al. 2020). The limestone karst in Laos is interesting for plant diversity, and several new species of Begonia were described, including $B$. cladotricha $M$. Hughes (Hughes
2007); B. viscosa Aver. \& H.Q. Nguyen (Averyanov \& Nguyen 2012); B. khammouanensis Souvann. \& Lamxay; B. hinnamnoensis Souvann. \& Lanors. (Souvannakhoummane et al. 2018); B. tatianae Aver; $B$. quadripetiolata Aver. \& H.Q. Nguyen (Averyanov et al. 2019).

During our field surveys in Khammouan and Bolikhamxay provinces, central Laos in June-August 2019 \& July-August 2020, and Champasak province, southern Laos in September 2020, we found two species of Begonia that morphologically placed in sect. Diploclinium (Lindl.) A.DC. after carefully checking relevant literature and comparing with herbarium specimens: FOF, HNL and KAG, as well as online specimen data and images of type available at Begonia Resource Centre (Hughes et al. 2015-). The first species

Citation: Phonepaseuth, P., P. Souladeth, S. Lanorsavanh, S. Tagane, T. Vongthavone \& K. Souvannakhoummane (2021). New distribution records of Begonia L., B. murina Craib and B. poilanei Kiew (Begoniaceae: Cucurbitales) for Laos. Journal of Threatened Taxa 13(12): 19849-19854. https://doi.org/10.11609/ jott.6856.13.12.19849-19854

Copyright: @ Phonepaseuth et al. 2021. Creative Commons Attribution 4.0 International License. JoTT allows unrestricted use, reproduction, and distribution of this article in any medium by providing adequate credit to the author(s) and the source of publication.

Funding: Botanical survey in Bolaven supported by Nagao Natural Environment Foundation. Botanical survey in central Laos by Sud Expert Plantes Développement Durable programme (AAP3-96)

Competing interests: The authors declare no competing interests.

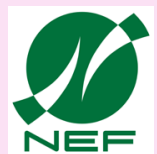

Acknowledgements: We are grateful to Sackda Phasavaeng, Visala Chounlamany, and Sisavath Chansavang for guiding the first author to Khammouan Province. The authors are grateful to the managers and staff of Dong Hua Sao National Protected Area for their permission to collect specimens in Bolaven Plateau. Thanks to Mark Hughes, Che-Wei Lin, and Thamarat Phutthai for their comments in species identification. We would also like to thank the curators of the herbaria FOF and HNL for their specimens accessible. Thank to Nagao Natural Environment Foundation, Japan for finance support field work in Bolaven plateau and thank you to the Sud Expert Plantes Développement Durable program (project AAP3-96) for supporting field trip in Central Laos. 
was identified as Begonia murina Craib, which can be recognized by small globose tuber and glandular hairs indumentum in all parts, red striation on ovary and fruit, these features had been known only in Thailand (Phutthai et al. 2019). The second species is B. poilanei Kiew which is characterized by elongated cylindric tuber and known from southern Vietnam and China (Kiew 2007; Tian 2014; Peng et al. 2014). We here report these two taxa as new to the flora of Laos, along with their description based on Lao materials, photographs, distribution map. Consequently, the diversity of Begonia in Laos is increased to 30 species. The descriptions were made based on the living plants, alcohol preserved and herbarium specimens. The terminology follows Phutthai et al. (2019).

\section{Begonia murina Craib}

(Figure 1, Image 1)

in Gard. Chron. ser. 3, 83: 66. 1928; Hughes \& Peng, 300 Spec. Port. Asian Begonia: 216. 2018; Phutthai et al., Fl. Thailand 14(3): 401. 2019.

Monoecious rhizomatous lithophytic herb, up to $15 \mathrm{~cm}$ tall. Rhizome tuber, small globose, smooth, light red to reddish brown, 3-5 $\mathrm{mm}$ in diameter, with many additional fibrous roots. Stemless or very short to 1 cm long, reddish, pilose. Leaves 3-5 per plant; petiole 5-9 cm long, 2-3 $\mathrm{mm}$ in diam., reddish, puberulous; blade asymmetric, ovate to lanceolate, 5-6 × 8-9 cm, apex acute, base cordate, margin dentate, covered with sparse short hairs, veins 4-5 per side, puberulous on both sides, adaxial surface green, abaxial surface paler. Inflorescence axillary near terminal cyme; peduncle erect, 6-10 cm long, puberulent, branched 2 times, with 2-4 male flowers and 1-2 female flowers per branch; bracts narrowly lanceolate, ca. $7 \times 3 \mathrm{~mm}$, membranous, reddish, slightly glandular hairy, margin fringed by glandular hairs. Staminate flower: pedicel $1.5-2.5 \mathrm{~cm}$ long, covered with glandular hairs, tepals 4 , white, unequal, outer 2 , broadly ovate, 10-12 × 14-15 $\mathrm{mm}$, glandular hairy on the outer surface, margin entire covered with glandular hairs, inner 2 , much smaller, elliptic to oblanceolate, white, $5-8 \times 1.5-2 \mathrm{~mm}$, glabrous inside, puberulous outside, margin entire, ciliate with glandular hairs; stamens bright yellow, 40-56, anther obovate, ca. $2 \mathrm{~mm}$ long. Pistillate flower: pedicel 1-1.2 cm long, glandular hairy, tepals 2 or 3, white, equal, outer 2, broadly ovate, 6-10 × 10-12 mm, covered with glandular hairs on the outer surface; inner 1 narrowly elliptic, ca. $6 \times 2 \mathrm{~mm}$. Ovary 3-locular, pale green with red striations, placentae axial, placentae 2 per locule, styles 3, stigmas bifid with twisted bands, golden yellow.
Capsule green with reddish line reticulate, brown when dry, with 3 subequal wings, abaxial wing 7-8 mm long, lateral wings shorter, 6-7 $\mathrm{mm}$ long. Seeds numerous, ellipsoid, ca. $0.3 \mathrm{~mm}$ long, light brown.

Distribution: Laos (Bolikhamxay, Khammouan), Thailand.

Ecology and Phenology: In Laos, this species was found on wet rock with mosses near streams in dry evergreen forest at elevation 1,034 m (Bolikhamxay Province) and on shade cliffs of limestone karst, associated with Paraboea sp. (Gesneriaceae), Amorphophalus sp. (Araceae) and some species of limestone ferns at elevation ca. $210 \mathrm{~m}$ (Khammouan Province). Flowering from August to September and fruiting from August to September.

Specimens examined: SL 1708 (FOF!, HNL!, Biology Herbarium of National University of Laos!), 28.vii.2020, in dry evergreen forest, Phou Khao Khouay National Protected Area, Thaphabath district, Bolikhamxay province, Laos, 18.496N, 103.313E, 1,034 m elevation, coll. Lanorsavanh S., Souvannakhoummane K. \& Khane; P002 (FOF!), 30.vii.2020, Pha Kataiy, Limestone Hill, Gnommarath District, Khammouan Province, Laos, 17.552N, 105.164E, 210 m elevation, coll. Phonepaseuth P.; 884, 26.ix.2020, ibid., coll. Souladeth P., Insisiengmai O., Sengthong A., Phengmala K., Phanpadith P.

Type: 113 (holo ABD digital image!, iso ABD digital image!), 11.xi.1927, Cult. Hort. Bot. Aberb., Thailand, coll. Kerr A.F.G.

Vernacular: สิ้มทุ๊ๆอิบ [(Somkoung Khon) meaning hairy begonia]

Note: Begonia murina Craib was originally described based on the plants collected from Kanchanaburi provinces, Thailand by Craib (1928), and formerly believed to be endemic to Thailand, being found in Sukhothai and Kanchanaburi (Phutthai et al. 2019). In Laos, it is known from Bolikhamxay and Khammouan provinces between 210-1,034 m elevations. Though Lao plants shows slight differences in leaf shape (obliquecordiform vs. usually reniform) and colour of veins (usually green vs. reddish green), we consider these are included within the infraspecific variation of this species.

\section{Begonia poilanei Kiew (Figure 1, Image 2)}

Adansonia 29(2): 235. (-238; fig. 2). 2007. Begonia intermedia D.K.Tian \& Y.H.Yan, Phytotaxa 166(2): 116 (2014), nom. Illeg.; Tian, Phytotaxa 172(1): 59. 2014. Begonia wuzhishanensis C.-I Peng, X.H. Jin \& S.M. Ku, Bot. Stud. (Taipei) 55-24:: 3. 2014; Tian, Phytotaxa 172(1): 59. 2014. 


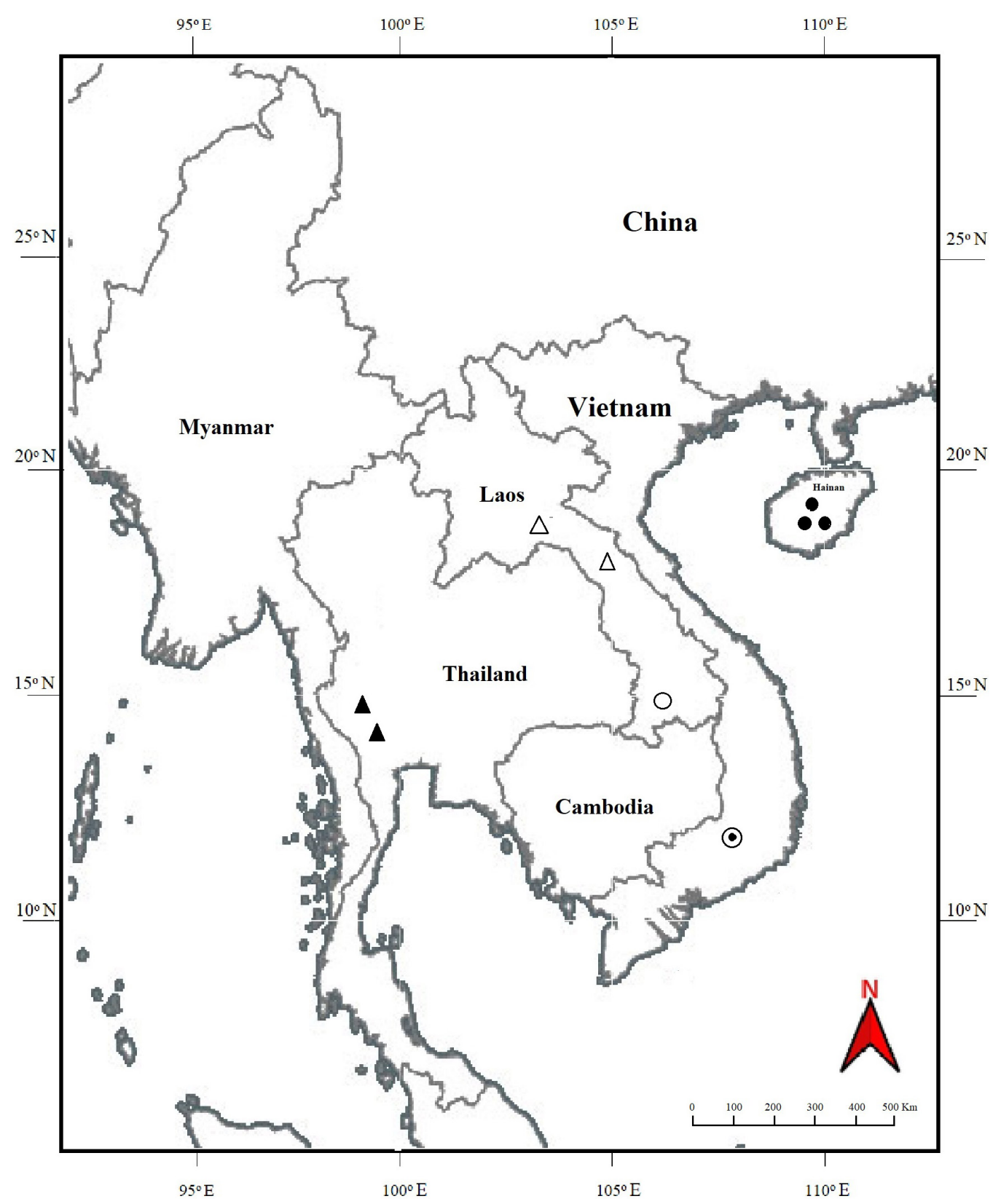

Figure 1. Distribution of Begonia murina Craib: $(\mathbf{A})$ in Thailand, and $(\triangle)$ in Bolikhamxay and Khammouan provinces, Laos. Begonia poilanei Kiew.: $(\odot)$ in Vietnam, $(\bigcirc)$ in Bolaven plateau, Laos and $(\bullet)$ in Hainan, China.

Monoecious rhizomatous lithophytic herb, 5-15 cm tall. Rhizome tuber, cylindrical, smooth, light brown, 2-4 cm long, 5-8 $\mathrm{mm}$ in diameter. Stem short, $0.5-3 \mathrm{~cm}$ long, reddish green, pilose; branched from lower nodes. Stipule narrowly triangular, ca. $5 \mathrm{~mm}$ long, covered with white hairs. Leaves $2(-5)$ per plant; petiole 5-6(-10) $\mathrm{cm}$ long, 2-3 $\mathrm{mm}$ in diameter, reddish green, puberulous; blade obliquely cordate, 6-7 × 7-9 cm, apex acutelanceolate or aristate, tip 1-1.5 cm long, base cordate, margin serrate with ciliate, puberulous on both sides, adaxial surface green, except venation which is dark green and impressed, leaf abaxial surface paler, and reddish-green or red in veins, veins 3-4 pair per side, prominent on abaxial side. Inflorescence axillary and terminal cyme; peduncle erect, 6-15 cm long, 2-3 mm in diameter, covered with short hairs, usually with 2 branches, with female flower more than male flowers per branch, floral bracts hirsute, ovate, 4-6 6 ca. $3 \mathrm{~mm}$, membranous, reddish-green. Staminate flower: pedicel red to pinkish-red, $1-1.8 \mathrm{~cm}$ long, ca. $1 \mathrm{~mm}$ in diameter, pubescent; tepals 4 , pink or bright pink, outer 2 larger, broadly ovate, $7-8 \times 9-10 \mathrm{~mm}$, with 9 distinct radial 

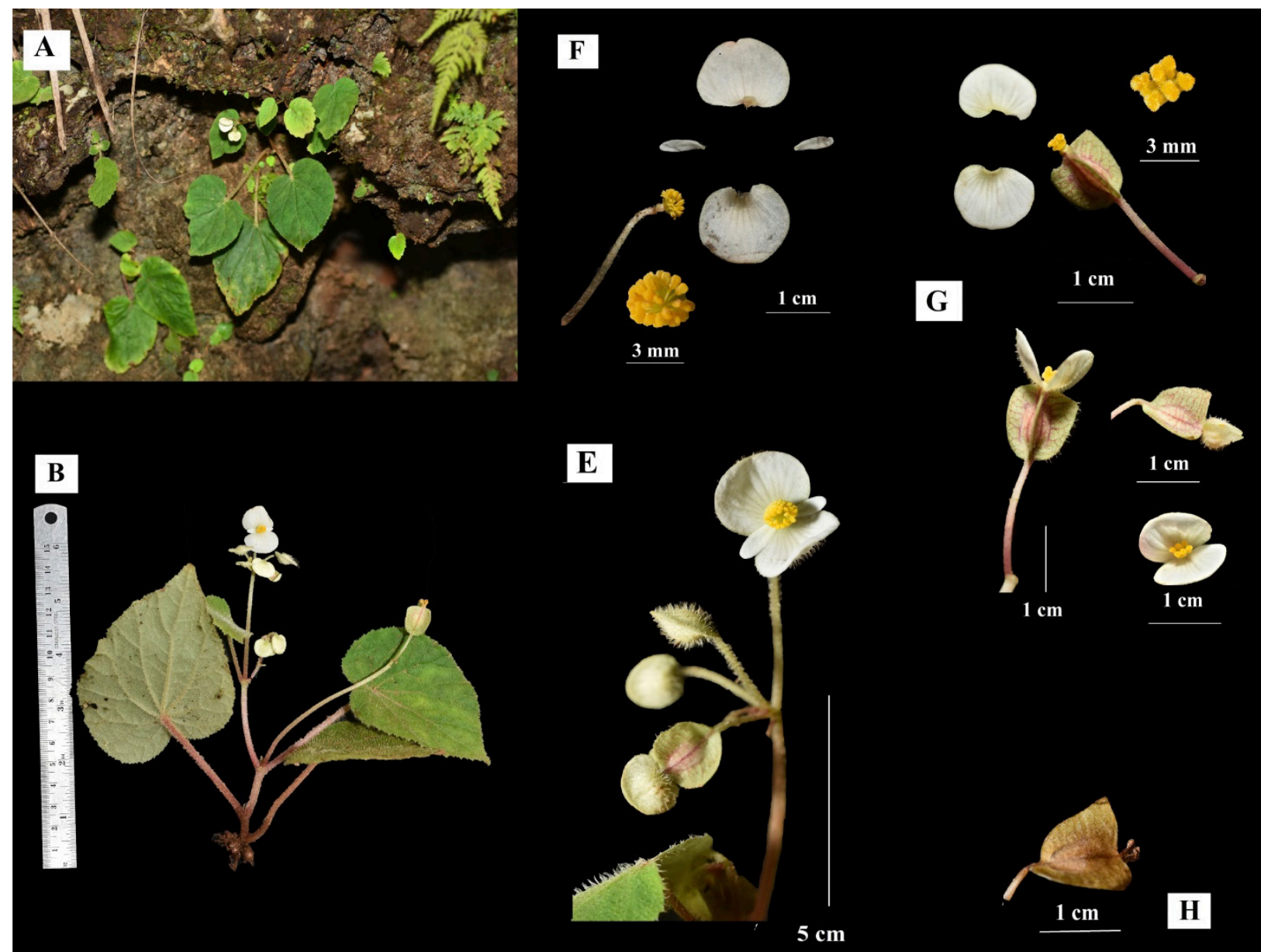

C

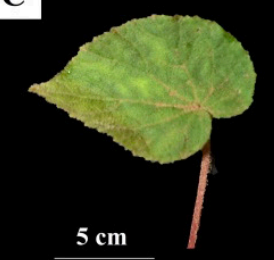

B

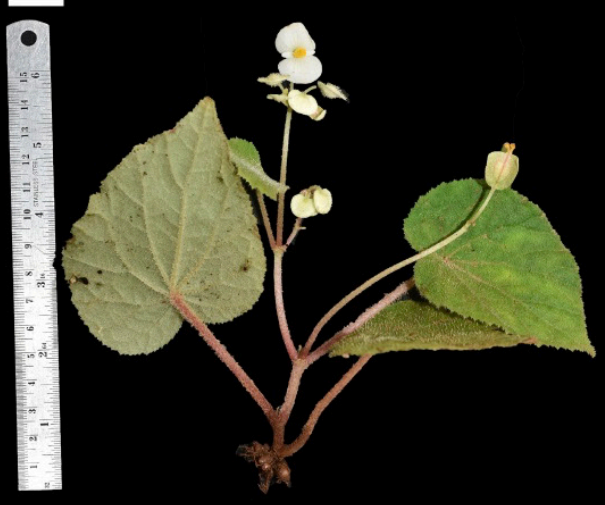

F

$\mathbf{E}$

$5 \mathrm{~cm}$

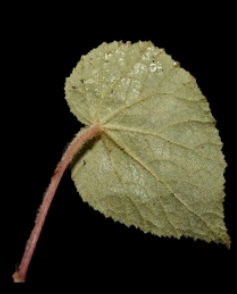

D

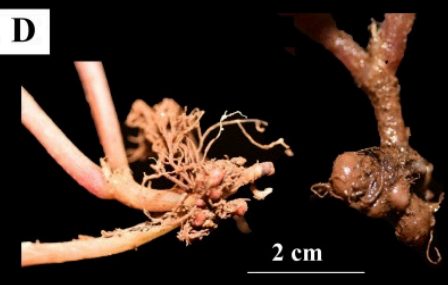

I

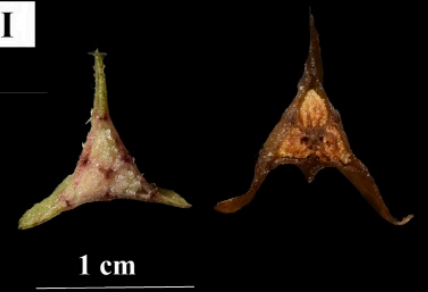

Image 1. Begonia murina Craib: A and B-Habitat and habit | C-Leaf adaxial surface (left) and leaf abaxial surface (right) | D-Tubers | E-Inflorescence | F-Staminate flower and stamens | G-Pistillate flowers and pistil | H-Mature fruit | I-Cross-sections of capsule. () P. Phonepaseuth from P002 (FOF).

stripes on adaxial surface with glandular hairy on the outer surface especially on margin entire, inner 2 , much smaller, elliptic to oblanceolate, lighter in color, 5-8 $\times$ 2-3 mm, stamens bright yellow, 28-36, anther obovate, ca. $2 \mathrm{~mm}$ long. Pistillate flower: pedicel pink or pinkish red, $1-1.2 \mathrm{~cm}$ long, globous, tepals 3 , pink, unequal, outer 2 , broadly ovate, 7-8 $\times 8-10 \mathrm{~mm}$, with 9 distinct radial stripes on adaxial surface, covered with glandular hairs on the midrib of outer surface, inner 1 , elliptic, ca. $1.5 \times 3 \mathrm{~mm}$, ovary 3-locular, pinkish green, shiny, placentae axial, placentae 2 per locule, styles 3, stigmas bifid, golden yellow. Capsule unequally 3-winged, abaxial wing oblong, 7-8 $\mathrm{mm}$ long, lateral wings shorter, 4-5 mm long. Seeds not seen.

Distribution: China, Laos (Bolaven Plateau), Vietnam.

Ecology and Phenology: In Laos, this species is known only from on top of the Bolaven Plateau, Paksong District, Champasak Province at 1,270 m elevation. 

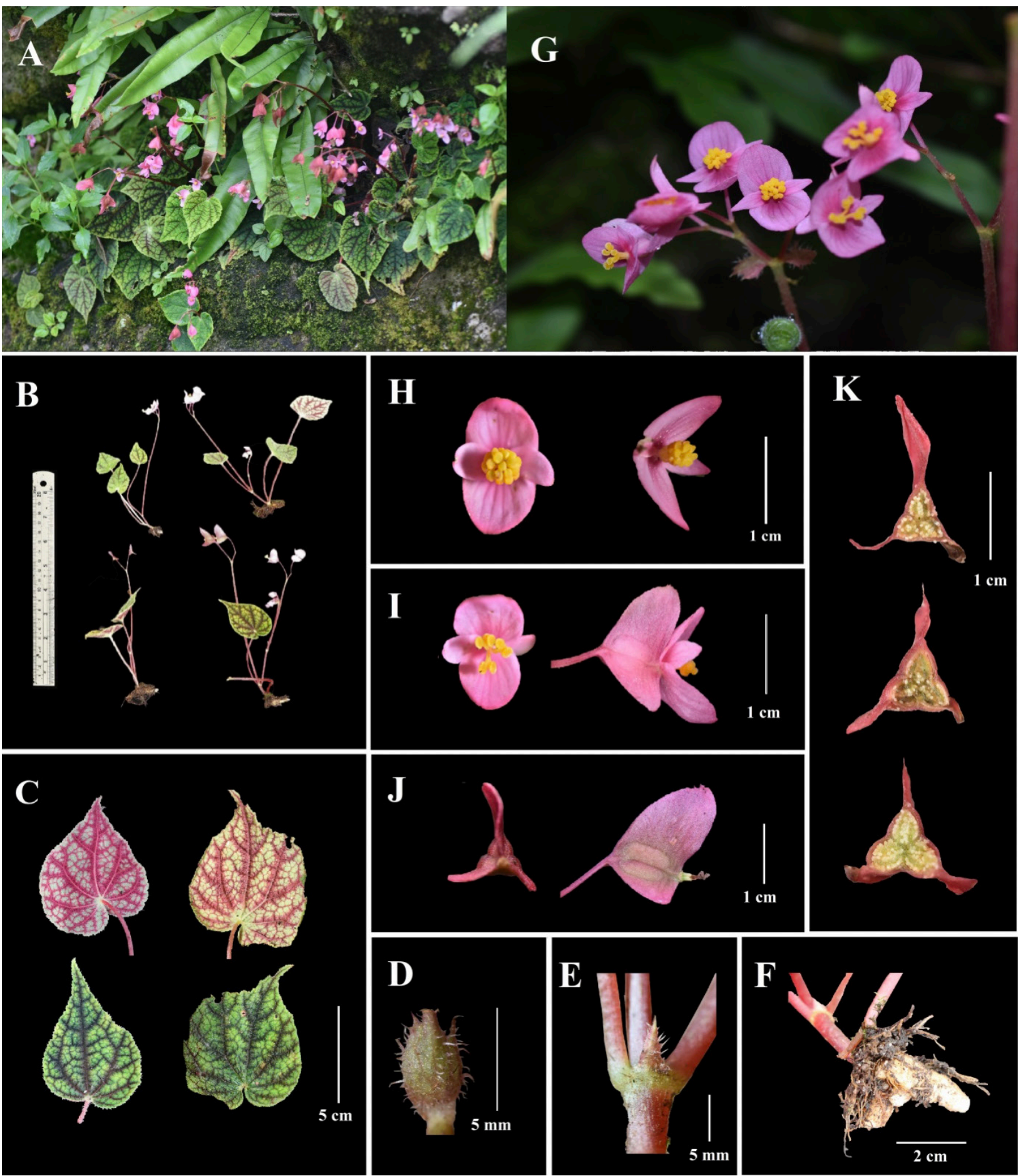

Image 2. Begonia poilanei Kiew: A and B-Habitat and habit | C-Leaf adaxial surface (below) and leaf abaxial surface (upper) | D-Floral bract | E-Stipule | F-Tuber | G-Inflorescences | $\mathrm{H}-$ Staminate flowers frontal and lateral view | I-Pistillate flowers frontal and lateral view | J-Mature fruits | K-Cross-sections of capsule. (C P. Phonepaseuth (A, C, D, E, G-K), K. Souvannakhoummane (B \& F) from L3949 (FOF).

Flowering and fruiting in September.

Specimens examined: L3949 (BKF, FOF!, KAG), 17.ix.2020, 15.060N, 106.208E, 1,277 m elevation, Dong Hua Sao National Protected Area, Bolaven Plateau, Paksong District, Champasak Province, Laos, coll.
Souladeth P., Phonepaseuth P., Souvannakhoummane K., \& Vongthavone $T$.

Type: 19824 (holo P [P00539147], digital image!, iso [P00539160, P00539161], digital image!), 21.x.1931, Djijuih Haut Donai District, Vietnam, Poilane E.; TDK710, 
holo CSH n.v, iso CSH n.v., 28.ix.2012, Yinggeling National Natural Reserve, Qiongzhong, Hainan, China, 19.020N, 109.573E; 2,093 m, holo HAST n.v., iso PE n.v., 3.xii.2013, on wet, mossy rocky slope by a stream in forest, Nanyi village, Fanyang township, Wuzhishan city, Hainan province, China, $18.881 \mathrm{~N}, 109.342 \mathrm{E}$, elevation ca. 180 $m$, coll. Shin-Ming Ku \& Xiao-Hua Jin.

Vernacular: สิ้มทุ่ๆภๆ๋มะจงบ (Somkoung Kammajon [meaning blood veins])

Note: Begonia poilanei Kiew was first descripted from Vietnam, Haut Donai District, Djijuih (Dalat) by Kiew in 2007, and named in honor of E. Poilane, who first discovered and collected this species in 1931. Formerly this species was stated as endemic to Vietnam. Peng et al. (2014) described Begonia wuzhishanensis C.-I Peng, X.H. Jin \& S.M. Ku from Wuzhishan City, Hainan Province, China, and Tian et al. (2014) also described B. intermedia D.K. Tian \& Y.H. Yan, from another city in Hainan Province in the same year, but both of them are now treated as a synonym of Begonia poilanei Kiew in Nomenclature of Begonia (Hughes et al. 2015-). In Laos, thus far this species is known only in one locality on the top plateau of Bolaven Plateau in Champasak Province. Lao plants have minor different from Vietnamese type specimen in its leaf apex: tip aristate (vs. acute).

\section{REFERENCES}

Averyanov, L.V. \& Q.H. Nguyen (2012). Eleven new species of Begonia L.(Begoniaceae) from Laos and Vietnam. Turczaninowia 15(2): 5-32. https://doi.org/10.11646/phytotaxa.208.1.1
Ding, H.B., M.B. Maw, B. Yang, S. Bouamanivong, \& Y.-H. Tan (2020). An updated checklist of Begonia (Begoniaceae) in Laos, with two new species and five new records. In: Jin X.-H., N.-H. Xia \& Y.-H. Tan (eds.) Plant diversity of Southeast Asia-II. PhytoKeys 138: 187-201. https://doi.org/10.3897/phytokeys.138.46718

Hughes, M. (2007). Begonia cladotricha (Begoniaceae): a new species from Laos. Edinburgh Journal of Botany 64(1): 101-105. https://doi. org/10.1017/S0960428607000777

Kiew, R. (2007). Notes on Vietnamese Begonia (Begoniaceae), including three new species. Adansonia 29(2): 229-238.

Lanorsavanh, S., M. Hughes, K. Souvannakhoummane \& V. Lamxay (2020). Begonia phouchomvoyensis (Begoniaceae), a new species from Lao PDR. Taiwania 65(1): 37-40. https://doi.org/10.6165/ tai.2020.65.37

Peng, C.I., X.H. Jin, S.M. Ku, Y. Kono, H.Y. Huang \& H.A. Yang (2014). Begonia wuzhishanensis (sect. Diploclinium, Begoniaceae), a new species from Hainan Island, China. Botanic Studies 55: 24. https:// doi.org/10.1186/1999-3110-55-24

Phutthai, T., M. Hughes \& K. Sridith (2019). Begoniaceae, pp. 359-431 In: Chayamrit, K \& Balslev, H. (eds.) Flora of Thailand 14(3). The Forest Herbarium, Department of National Parks, Wildlife and Plant Conservation, Bangkok, Thailand, 72pp.

Hughes, M., P.W. Moonlight, A. Jara-Muñoz, M.C. Tebbitt, H.P. Wilson \& M. Pullan (2015-). Begonia Resource Centre. Online database available from http://padme.rbge.org.uk/begonia/ (Accessed 15 September 2020)

Souvannakhoummane, K., M. Hughes \& S. Lanorsavanh (2016). Begonia lamxayiana Souvann. (Begoniaceae): a new species from Lao PDR. Thai Journal of Botany 8(1): 1-5.

Souvannakhoummane, K., S. Lanorsavanh, \& V. Lamxay (2018). Two new species of Begonia L. (Begoniaceae) from central Laos. Taiwania 63(3): 188-194. https://doi.org/10.6165/tai.2018.63.188

Souvannakhoummane, K., S. Lanorsavanh, J.H. Park, H. Kang, T.H. Ahn, S. Xayalath \& C. Phongoudom (2020). Begonia colliculata (Begoniaceae), a new species from Nam Kading National Protected Area, Bolikhamxai province, Laos. Thai Forest Bulletin (Botany) 48(2): 108-113. https://doi.org/10.20531/tfb.2020.48.2.04

Tian, D. (2014). Begonia intermedia, an illegitimate name and taxonomic synonym of $B$. wuzhishanensis. Phytotaxa 172(1): 59-60. https://doi.org/10.11646/phytotaxa.172.1.10 
Dr. Albert G. Orr, Griffith University, Nathan, Australia

Dr. Sameer Padhye, Katholieke Universiteit Leuven, Belgium

Dr. Nancy van der Poorten, Toronto, Canada

Dr. Kareen Schnabel, NIWA, Wellington, New Zealand

Dr. R.M. Sharma, (Retd.) Scientist, Zoological Survey of India, Pune, India

Dr. Manju Siliwal, WILD, Coimbatore, Tamil Nadu, India

Dr. G.P. Sinha, Botanical Survey of India, Allahabad, India

Dr. K.A. Subramanian, Zoological Survey of India, New Alipore, Kolkata, India

Dr. P.M. Sureshan, Zoological Survey of India, Kozhikode, Kerala, India

Dr. R. Varatharajan, Manipur University, Imphal, Manipur, India

Dr. Eduard Vives, Museu de Ciències Naturals de Barcelona, Terrassa, Spain

Dr. James Young, Hong Kong Lepidopterists' Society, Hong Kong

Dr. R. Sundararaj, Institute of Wood Science \& Technology, Bengaluru, India

Dr. M. Nithyanandan, Environmental Department, La Ala Al Kuwait Real Estate. Co. K.S.C., Kuwait

Dr. Himender Bharti, Punjabi University, Punjab, India

Mr. Purnendu Roy, London, UK

Dr. Saito Motoki, The Butterfly Society of Japan, Tokyo, Japan

Dr. Sanjay Sondhi, TITLI TRUST, Kalpavriksh, Dehradun, India

Dr. Nguyen Thi Phuong Lien, Vietnam Academy of Science and Technology, Hanoi, Vietnam

Dr. Nitin Kulkarni, Tropical Research Institute, Jabalpur, India

Dr. Robin Wen Jiang Ngiam, National Parks Board, Singapore

Dr. Lional Monod, Natural History Museum of Geneva, Genève, Switzerland.

Dr. Asheesh Shivam, Nehru Gram Bharti University, Allahabad, India

Dr. Rosana Moreira da Rocha, Universidade Federal do Paraná, Curitiba, Brasil

Dr. Kurt R. Arnold, North Dakota State University, Saxony, Germany

Dr. James M. Carpenter, American Museum of Natural History, New York, USA

Dr. David M. Claborn, Missouri State University, Springfield, USA

Dr. Kareen Schnabel, Marine Biologist, Wellington, New Zealand

Dr. Amazonas Chagas Júnior, Universidade Federal de Mato Grosso, Cuiabá, Brasil

Mr. Monsoon Jyoti Gogoi, Assam University, Silchar, Assam, India

Dr. Heo Chong Chin, Universiti Teknologi MARA (UiTM), Selangor, Malaysia

Dr. R.J. Shiel, University of Adelaide, SA 5005, Australia

Dr. Siddharth Kulkarni, The George Washington University, Washington, USA

Dr. Priyadarsanan Dharma Rajan, ATREE, Bengaluru, India

Dr. Phil Alderslade, CSIRO Marine And Atmospheric Research, Hobart, Australia

Dr. John E.N. Veron, Coral Reef Research, Townsville, Australia

Dr. Daniel Whitmore, State Museum of Natural History Stuttgart, Rosenstein, Germany.

Dr. Yu-Feng Hsu, National Taiwan Normal University, Taipei City, Taiwan

Dr. Keith V. Wolfe, Antioch, California, USA

Dr. Siddharth Kulkarni, The Hormiga Lab, The George Washington University, Washington,

D.C., USA

Dr. Tomas Ditrich, Faculty of Education, University of South Bohemia in Ceske

Budejovice, Czech Republic

Dr. Mihaly Foldvari, Natural History Museum, University of Oslo, Norway

Dr. V.P. Uniyal, Wildlife Institute of India, Dehradun, Uttarakhand 248001, India

Dr. John T.D. Caleb, Zoological Survey of India, Kolkata, West Bengal, India

Dr. Priyadarsanan Dharma Rajan, Ashoka Trust for Research in Ecology and the Environment (ATREE), Royal Enclave, Bangalore, Karnataka, India

\section{Fishes}

Dr. Neelesh Dahanukar, IISER, Pune, Maharashtra, India

Dr. Topiltzin Contreras MacBeath, Universidad Autónoma del estado de Morelos, México

Dr. Heok Hee Ng, National University of Singapore, Science Drive, Singapore

Dr. Rajeev Raghavan, St. Albert's College, Kochi, Kerala, India

Dr. Robert D. Sluka, Chiltern Gateway Project, A Rocha UK, Southall, Middlesex, UK

Dr. E. Vivekanandan, Central Marine Fisheries Research Institute, Chennai, India

Dr. Davor Zanella, University of Zagreb, Zagreb, Croatia

Dr. A. Biju Kumar, University of Kerala, Thiruvananthapuram, Kerala, India

Dr. Akhilesh K.V., ICAR-Central Marine Fisheries Research Institute, Mumbai Research

Centre, Mumbai, Maharashtra, India

Dr. J.A. Johnson, Wildlife Institute of India, Dehradun, Uttarakhand, India

\section{Amphibians}

Dr. Sushil K. Dutta, Indian Institute of Science, Bengaluru, Karnataka, India

Dr. Annemarie Ohler, Muséum national d'Histoire naturelle, Paris, France

\section{Reptiles}

Dr. Gernot Vogel, Heidelberg, Germany

Dr. Raju Vyas, Vadodara, Gujarat, India

Dr. Pritpal S. Soorae, Environment Agency, Abu Dubai, UAE.

Prof. Dr. Wayne J. Fuller, Near East University, Mersin, Turkey

Prof. Chandrashekher U. Rivonker, Goa University, Taleigao Plateau, Goa. India

Dr. S.R. Ganesh, Chennai Snake Park, Chennai, Tamil Nadu, India

Dr. Himansu Sekhar Das, Terrestrial \& Marine Biodiversity, Abu Dhabi, UAE
Birds

Dr. Hem Sagar Baral, Charles Sturt University, NSW Australia

Dr. Chris Bowden, Royal Society for the Protection of Birds, Sandy, UK

Dr. Priya Davidar, Pondicherry University, Kalapet, Puducherry, India

Dr. J.W. Duckworth, IUCN SSC, Bath, UK

Dr. Rajah Jayapal, SACON, Coimbatore, Tamil Nadu, India

Dr. Rajiv S. Kalsi, M.L.N. College, Yamuna Nagar, Haryana, India

Dr. V. Santharam, Rishi Valley Education Centre, Chittoor Dt., Andhra Pradesh, India

Dr. S. Balachandran, Bombay Natural History Society, Mumbai, India

Mr. J. Praveen, Bengaluru, India

Dr. C. Srinivasulu, Osmania University, Hyderabad, India

Dr. K.S. Gopi Sundar, International Crane Foundation, Baraboo, USA

Dr. Gombobaatar Sundev, Professor of Ornithology, Ulaanbaatar, Mongolia

Prof. Reuven Yosef, International Birding \& Research Centre, Eilat, Israel

Dr. Taej Mundkur, Wetlands International, Wageningen, The Netherlands

Dr. Carol Inskipp, Bishop Auckland Co., Durham, UK

Dr. Tim Inskipp, Bishop Auckland Co, Durham, UK

Dr. V. Gokula, National College, Tiruchirappalli, Tamil Nadu, India

Dr. Arkady Lelej, Russian Academy of Sciences, Vladivostok, Russia

Dr. Simon Dowell, Science Director, Chester Zoo, UK

Dr. Mário Gabriel Santiago dos Santos, Universidade de Trás-os-Montes e Alto Douro,

Quinta de Prados, Vila Real, Portugal

Dr. Grant Connette, Smithsonian Institution, Royal, VA, USA

Dr. M. Zafar-ul Islam, Prince Saud Al Faisal Wildlife Research Center, Taif, Saudi Arabia

Mammals

Dr. Giovanni Amori, CNR - Institute of Ecosystem Studies, Rome, Italy

Dr. Anwaruddin Chowdhury, Guwahati, India

Dr. David Mallon, Zoological Society of London, UK

Dr. Shomita Mukherjee, SACON, Coimbatore, Tamil Nadu, India

Dr. Angie Appel, Wild Cat Network, Germany

Dr. P.O. Nameer, Kerala Agricultural University, Thrissur, Kerala, India

Dr. Ian Redmond, UNEP Convention on Migratory Species, Lansdown, UK

Dr. Heidi S. Riddle, Riddle's Elephant and Wildlife Sanctuary, Arkansas, USA

Dr. Karin Schwartz, George Mason University, Fairfax, Virginia.

Dr. Lala A.K. Singh, Bhubaneswar, Orissa, India

Dr. Mewa Singh, Mysore University, Mysore, India

Dr. Paul Racey, University of Exeter, Devon, UK

Dr. Honnavalli N. Kumara, SACON, Anaikatty P.O., Coimbatore, Tamil Nadu, India

Dr. Nishith Dharaiya, HNG University, Patan, Gujarat, India

Dr. Spartaco Gippoliti, Socio Onorario Società Italiana per la Storia della Fauna "Giuseppe

Altobello", Rome, Italy

Dr. Justus Joshua, Green Future Foundation, Tiruchirapalli, Tamil Nadu, India

Dr. H. Raghuram, The American College, Madurai, Tamil Nadu, India

Dr. Paul Bates, Harison Institute, Kent, UK

Dr. Jim Sanderson, Small Wild Cat Conservation Foundation, Hartford, USA

Dr. Dan Challender, University of Kent, Canterbury, UK

Dr. David Mallon, Manchester Metropolitan University, Derbyshire, UK

Dr. Brian L. Cypher, California State University-Stanislaus, Bakersfield, CA

Dr. S.S. Talmale, Zoological Survey of India, Pune, Maharashtra, India

Prof. Karan Bahadur Shah, Budhanilakantha Municipality, Kathmandu, Nepal

Dr. Susan Cheyne, Borneo Nature Foundation International, Palangkaraja, Indonesia

Dr. Hemanta Kafley, Wildlife Sciences, Tarleton State University, Texas, USA

\section{Other Disciplines}

Dr. Aniruddha Belsare, Columbia MO 65203, USA (Veterinary)

Dr. Mandar S. Paingankar, University of Pune, Pune, Maharashtra, India (Molecular)

Dr. Jack Tordoff, Critical Ecosystem Partnership Fund, Arlington, USA (Communities)

Dr. Ulrike Streicher, University of Oregon, Eugene, USA (Veterinary)

Dr. Hari Balasubramanian, EcoAdvisors, Nova Scotia, Canada (Communities)

Dr. Rayanna Hellem Santos Bezerra, Universidade Federal de Sergipe, São Cristóvão, Brazil

Dr. Jamie R. Wood, Landcare Research, Canterbury, New Zealand

Dr. Wendy Collinson-Jonker, Endangered Wildlife Trust, Gauteng, South Africa

Dr. Rajeshkumar G. Jani, Anand Agricultural University, Anand, Gujarat, India

Dr. O.N. Tiwari, Senior Scientist, ICAR-Indian Agricultural Research Institute (IARI), New

Delhi, India

Dr. L.D. Singla, Guru Angad Dev Veterinary and Animal Sciences University, Ludhiana, India

Dr. Rupika S. Rajakaruna, University of Peradeniya, Peradeniya, Sri Lanka

Dr. Bahar Baviskar, Wild-CER, Nagpur, Maharashtra 440013, India

Reviewers 2018-2020

Due to pausity of space, the list of reviewers for 2018-2020 is available online.
The opinions expressed by the authors do not reflect the views of the Journal of Threatened Taxa, Wildlife Information Liaison Development Society, Zoo Outreach Organization, or any of the partners. The journal, the publisher, the host, and the partners are not responsible for the accuracy of the political boundaries shown in the maps by the authors.

\footnotetext{
Print copies of the Journal are available at cost. Write to:

The Managing Editor, JoTT,

c/o Wildlife Information Liaison Development Society,

No. 12, Thiruvannamalai Nagar, Saravanampatti - Kalapatti Road,

Saravanampatti, Coimbatore, Tamil Nadu 641035, India

ravi@threatenedtaxa.org
} 


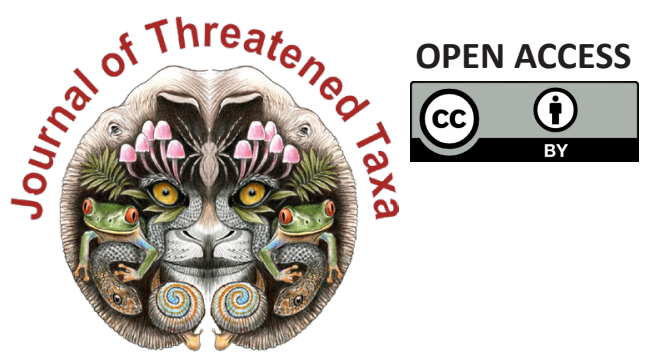

www.threatenedtaxa.org

The Journal of Threatened Taxa (JoTT) is dedicated to building evidence for conservation globally by publishing peer-reviewed articles online every month at a reasonably rapid rate at www.threatenedtaxa.org. All articles published in JoTT are registered under Creative Commons Attribution 4.0 International License unless otherwise mentioned. JoTT allows allows unrestricted use, reproduction, and distribution of articles in any medium by providing adequate credit to the author(s) and the source of publication.

\section{ISSN $0974-7907$ (Online) | ISSN $0974-7893$ (Print)}

\section{October 2021 | Vol. 13 | No. 12 | Pages: 19675-19886 \\ Date of Publication: 26 October 2021 (Online \& Print) DOI: 10.11609/jott.2021.13.12.19675-19886}

Articles

Roosting habits and habitats of the Indian Flying Fox Pteropus medius Temminck, 1825 in the northern districts of Tamil Nadu, India

- M. Pandian \& S. Suresh, Pp. 19675-19688

Diversity and distribution of avifauna at Warathenna-Hakkinda Environmental Protection Area in Kandy, Sri Lanka

- Dinelka Thilakarathne, Tithira Lakkana, Gayan Hirimuthugoda, Chaminda Wijesundara \& Shalika Kumburegama, Pp. 19689-19701

Grass species composition in tropical forest of southern India

- M. Ashokkumar, S. Swaminathan \& R. Nagarajan, Pp. 19702-19713

\section{Communications}

Habitat use and conservation threats to Wild Water Buffalo Bubalus arnee (Mammalia: Artiodactyla: Bovidae) in Koshi Tappu Wildlife Reserve, Nepal

- Reeta Khulal, Bijaya Neupane, Bijaya Dhami, Siddhartha Regmi, Ganesh Prasad Tiwari \& Manita Parajuli, Pp. 19714-19724

Get my head around owls: people perception and knowledge about owls of Andaman Islands

- Shanmugavel Sureshmarimuthu, Santhanakrishnan Babu, Nagaraj Rajeshkumar \& Honnavalli Nagaraj Kumara, Pp. 19725-19732

Abundance and diversity of threatened birds in Nangal Wetland, Punjab, India - Rajwinder Kaur \& Onkar Singh Brraich, Pp. 19733-19742

Evaluation of fish diversity and abundance in the Kabul River with comparisons between reaches above and below Kabul City, Afghanistan

- Ugyen Kelzang, Ahmad Farid Habibi \& Ryan J. Thoni, Pp. 19743-19752

New record of Myrmarachne melanocephala MacLeay, 1839 (Araneae: Salticidae) from Jharkhand, India and biogeographical implications of the co-occurrence of its ant model Tetraponera rufonigra Jerdon, 1851

- Rahul Kumar, Mirtunjay Sharma \& Ajay Kumar Sharma, Pp. 19753-19761

Diversity of spiders (Arachnida: Araneae) and the impact of pruning in Indian sandalwood plantations from Karnataka, India

-S. Padma 1 \& R. Sundararaj, Pp. 19762-19772

New records of cheilostome Bryozoa from the eastern coast of India encrusting on the exoskeleton of live horseshoe crabs of Indian Sundarbans

- Swati Das, Maria Susan Sanjay, Basudev Tripathy, C. Venkatraman \& K.A. Subramanian, Pp. 19773-19780

On the pteridophytes of Bherjan-Borajan-Padumoni Wildlife Sanctuary, Assam, India - Pranjal Borah \& Jayanta Barukial, Pp. 19781-19790

Population status of Heritiera fomes Buch.-Ham., a threatened species from Mahanadi Mangrove Wetland, India

- Sudam Charan Sahu, Manas Ranjan Mohanta \& N.H. Ravindranath, Pp. 19791-19798

Additions to the lichenized and lichenicolous fungi of Jammu \& Kashmir from Kishtwar High Altitude National Park

- Vishal Kumar, Yash Pal Sharma, Siljo Joseph, Roshinikumar Ngangom \& Sanjeeva Nayaka, Pp. 19799-19807

\section{Short Communications}

Is release of rehabilitated wildlife with embedded lead ammunition advisable? Plumbism in a Jaguar Panthera Onca (Mammalia: Carnivora: Felidae), survivor of gunshot wounds - Eduardo A. Díaz, Carolina Sáenz, E. Santiago Jiménez, David A. Egas \& Kelly Swing, Pp. 19808-19812

New record of the Sewing Needle Zipper Loach Paracanthocobitis linypha Singer \& Page, 2015 (Teleostei: Cypriniformes: Nemacheilidae) from the Chindwin drainage of Manipur, India

- Yumnam Rameshori, Yengkhom Chinglemba \& Waikhom Vishwanath, Pp. 19813-19817

Field identification characters to diagnose Microhyla mukhlesuri from closely related M. mymensinghensis (Amphibia: Microhylidae) and range extension of $M$. mukhlesuri up to West Bengal State, India

- Suman Pratihar \& Kaushik Deuti, Pp. 19818-19823
First report of Scipinia horrida (Stål) (Heteroptera: Reduviidae) from Assam, with comments on related genus Irantha Stål

- Anjana Singha Naorem, Santana Saikia, Anandita Buragohain, Rubina Azmeera Begum, Swapnil S. Boyane \& Hemant V. Ghate, Pp. 19824-19830

Flesh fly (Diptera: Sarcophagidae): male terminalia, diversity and expanded geographical distribution from India

- Kanholi Sreejith, Shuvra Kanti Sinha, Santanu Mahato \& Edamana Pushpalatha, Pp. 1983119836

Checklist of moths (Heterocera) of Tadong, Sikkim, India

- Prayash Chettri, Yuki Matsui, Hideshi Naka \& Archana Tiwari, Pp. 19837-19848

New distribution records of Begonia L., B. murina Craib and B. poilanei Kiew (Begoniaceae: Cucurbitales) for Laos

- Phongphayboun Phonepaseuth, Phetlasy Souladeth, Soulivanh Lanorsavanh, Shuichiro Tagane, Thyraphon Vongthavone \& Keooudone Souvannakhoummane Pp. 19849-19854

Notes

A recent sighting of the Stripe-backed Weasel Mustela strigidorsa (Mammalia: Carnivora: Mustelidae) in Hkakabo Razi Landscape, Myanmar

- Sai Sein Lin Oo, Tun Tun, Kyaw Myo Naing \& Paul Jeremy James Bates, Pp. 19855-19859

Are the uplifted reef beds in North Andaman letting nesting Olive Ridley Sea Turtle Lepidochelys olivacea stranded?

- Nehru Prabakaran, Anoop Raj Singh \& Vedagiri Thirumurugan, Pp. 19860-19863

First record of the orb-weaving spider Araneus tubabdominus Zhu \& Zhang, 1993 (Araneae: Araneidae) from India

- Souvik Sen, John T.D. Caleb \& Shelley Acharya, Pp. 19864-19866

The genus Catapiestus Perty, 1831 (Coleoptera: Tenebrionidae: Cnodalonini) from Arunachal Pradesh with one new record to India

- V.D. Hegde \& Sarita Yadav, Pp. 19867-19869

Rediscovery and extended distribution of Indigofera santapaui Sanjappa (Leguminosae: Papilionoideae) from the states of Maharashtra and Gujarat, India

- Kumar Vinod Chhotupuri Gosavi, Sanjay Gajanan Auti, Sharad Suresh Kambale \& Munivenkatappa Sanjappa, Pp. 19870-19873

Additional distribution records of Ceropegia anjanerica, an endemic and 'Endangered' lantern flower of the northern Western Ghats, India

- Samir Shrikant Maity, Ajay Natha Gangurde, Sharad Suresh Kambale, Avinash Ramchandra Gholave, Avinash Asraji Adsul, Ganesh Babaso Pawar \& Kumar Vinod Chhotupuri Gosavi, Pp. 19874-19877

Notes on the extended distribution of Impatiens megamalayana, a recently described balsam in Western Ghats, India

- Anoop P. Balan \& A.J. Robi, Pp. 19878-19883

Book Review

A look over on the scented tree of India (Santalum album - S. Suresh Ramanan \& A. Arunachalam, Pp. 19884-19886
Publisher \& Host
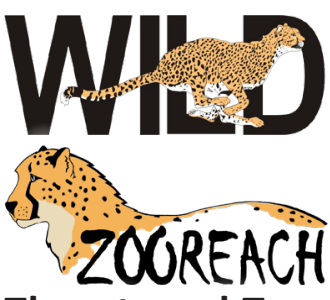

Threatened Taxa 